\title{
PENGARUH KOMISARIS INDEPENDEN DAN KARAKTERISTIK KOMITE AUDIT TERHADAP INTERNET FINANCIAL REPORTING DISCLOSURE
}

\author{
Rudi Zulfikar", Nana Nofianti**, Azy Nur Faozy ${ }^{* * *}$ \\ *Fakultas Ekonomi, Jurusan Akuntansi, Universitas Sultan Ageng Tirtayasa, rz-zulfikar72@untirta.ac.id \\ **Fakultas Ekonomi, Jurusan Akuntansi, Universitas Sultan Ageng Tirtayasa, nnofianti@untirta.ac.id \\ ***Fakultas Ekonomi, Jurusan Akuntansi, Universitas Sultan Ageng Tirtayasa, azynurfaozy@gmail.com
}

Article history:

\section{Received 16 Maret 2019}

Received in Revised 11 Agustus 2019

Accepted 22 November 2019

Keywords:

Internet financial reporting disclosure, Komisaris Independen dan Karakteristik Komite Audit
ABSTRACT
This study aims to analyze the effect of the proportion of Independent Commissioners and the characteristics of the Audit Committee on disclosure of internet financial reporting. The sample in this study was 90 companies, and the sample used in this study was a banking company registered at Bank Indonesia during 2011-2014.

Based on the test results show that the proportion of independent commissioners, has no effect on disclosure of financial reporting on the internet. And then, the characteristics of the audit committee consist of several proxies namely the size of the Audit Committee, the frequency of Audit Committee meetings, the expertise of the Audit Committee in finance / accounting, and the independent Audit Committee has a positive and significant effect for disclosure of internet financial reporting. Size as a control variable has a positive and significant effect on disclosure of internet financial reporting.

Penelitian ini bertujuan untuk menganalisis pengaruh proporsi Komisaris Independen dan karakteristik Komite Audit terhadap pengungkapan pelaporan keuangan internet. Sampel dalam penelitian ini adalah 90 perusahaan, dan sampel yang digunakan dalam penelitian ini adalah perusahaan perbankan yang terdaftar di Bank Indonesia selama tahun 2011-2014.

Berdasarkan hasil pengujian menunjukkan bahwa proporsi komisaris independen, tidak berpengaruh terhadap pengungkapan pelaporan keuangan di internet. Dan kemudian, karakteristik komite audit terdiri dari beberapa proksi yaitu ukuran Komite Audit, frekuensi rapat Komite Audit, keahlian Komite Audit di bidang keuangan / akuntansi, dan pihak independen Komite Audit memiliki efek positif dan signifikan untuk pengungkapan pelaporan keuangan internet. Ukuran sebagai variabel kontrol berpengaruh positif dan signifikan terhadap pengungkapan pelaporan keuangan internet.

AKUISISI : Jurnal Akuntansi

Website : http://www.fe.ummetro.ac.id/ejournal/index.php/JA

This is an open access article distributed under the terms of the Creative Commons Attribution 4.0 International License, which permits unrestricted use, distribution, and reproduction in any medium, provided the original work is properly cited. 


\section{PENDAHULUAN}

Menurut Fair Finance Guide Internasional (2010) tentang transparansi dan akuntabilitas sektor perbankan terdapat 48 bank di Tujuh negara yang dapat rapor merah transparansi salah satunya Indonesia. Selanjutnya tingkat kepatuhan mandatory disclosure industri perbankan di Indonesia memiliki rerata 75,92\%, angka ini masih tergolong rendah jika dibandingkan dengan ketentuan pengungkapan $100,00 \%$ oleh BAPEPAM-LK (Suhardjantoat al., 2014). Fenomena tersebut mengindikasikan masih kurangnya tingkat transparansi dan kepatuhan pengungkapan, salah satunya Internet Financial Reporting Disclosure

Dalam upaya mendorong meningkatkan akuntabilitas dan tranparansi perusahaan maka diperlukan mekanisme monitoring. Monitoring dilakukan melalui mekanisme internal Board, salah satunya Komisaris Independen dan Komite Audit. Monitoring internal dapat mengarahkan, memantau dan mengevaluasi pelaksanaan kebijakan strategis bank, hal ini sesuai dengan PBI No. 8/14/PBI/ 2006 pasal 9 ayat 3.Komisaris Independen merupakan seorang yang independen dari posisi manajemen eksekutif atau fungsi manajemen lainnya dalam perusahaan dan bebas dari hubungan apapun yang dapat mempengaruhi keputusan mereka (Hegazy dan Hegazy, 2010). Sedangkan Komite Audit merupakan aspek governance memastika kualitas audit dan pengawasan pelaporan keuangan melalui internet (Ika dan Ghozali 2011). Komisaris Independen dan Komite Audit diperlukan pihak yang dapat mewakili principal dan stakeholders dalam memonitor aktivitas manajemen sehingga mendorong manajemen untuk meningkatkan pengelolaan organisasi menjadi lebih optimal sehingga meningkatkan kepercayaan shareholders dan stakeholder

Ayuso dan Argondana (2007) menyatakan bahwa Komisaris Independen lebih efektif dalam melakukan pengawasan terhadap perusahaan karena kepentingan mereka tidak terganggu oleh ketergantungan pada organisasi. Sementara itu, DeZoort-Salterio (2001) berpendapat bahwa ahli keuangan dalam sebuah Komite Audit meningkatkan kemungkinan temuan kesalahan penyataan yang material (material misstatement), sehingga dapat dikomunikasikan dan dikoreksi secara tepat waktu.

Perbedaan penelitian ini dengan penelitian sebelumnya Debrecenyet al., (2002) dan Bottiet al., (2014) yaitu penggunaan mekanisme monitoring internal Governance diproksikan oleh Komisaris Independen dan karakteristik Komiter Audit. Selanjutnya Penelitian ini dengan konteks di Industri perbankan Indonesia.

\section{TINJAUAN PUSTAKA}

Agency Theory

Jensen dan Meckling (1976) mendefinisikan agency relationship sebagai kontrak yang ditetapkan antara prinsipal yang menggunakan jasa agen untuk menjalankan kegiatan usaha dan bekerja untuk kepentingan prinsipal. Manajer sebagai penerima pendelegasian wewenang untuk mengelola perusahaan semestinya dalam setiap tindakaannya selalu bertujuan untuk meningkatkan kesejahteraan pemilik. Tujuan manajer dan pemilik semestinya selalu selaras yaitu meningkatkan nilai perusahaan (value maximizing). Manajemen dalam pengelolaan bank harus berdasarkan peraturan yang berlaku. Hal ini sesuai dengan pendapat Avdasheva dan Yakovlev (2000) pengelolaan bank dengan prinsip kehati-hatian (prudential) yaitu berdasarkan peraturan yang berlaku merupakan bentuk akuntabilitas manajemen terhadap pemilik dan masyarakat. Namun, kenyataannya tujuan setiap pihak tidak selalu sejalan. Manajer lebih risk averse daripada pemegang saham (Donald, 2010). Berdasarkan penjelasan Jensen dan Meckling (1976) di atas dapat disimpulkan bahwa hubungan keagenan adalah hubungan kontraktual antara prinsipal dan agen dalam organisasi.

Konflik keagenan antara regulator dengan pemilik dan manajer dengan pemilik dapat menimbulkan masalah moral hazard, karena tindakan tersebut mempengaruhi tingkat risiko bank. (Dewatripont dan Tirole, 1994; Pinteris,2002; dan Supriyatno, 2006; Landsman, 2006). Asimetri informasi antara deposan dengan manajemen bank terjadi karena bank mendapatkan dana dari investor individual (deposan) dengan jumlahnya banyak, tetapi deposan tidak mempunyai pengetahuan sebaik manajemen bank tentang nilai aset bank dan kekuatan modal bank serta potensi kebangkrutan bank sesungguhnya (Chu,1999). Manajer lebih mengetahui indikasi yang dapat menimbulkan kebangkrutan lebih dini dan lebih lengkap karena manajemen lebih mempunyai akses berbagai jenis informasi dari pada deposan. Penyebab lain yaitu rendahnya keinginan para deposan melakukan berbagai fungsi monitoring karena deposan kurang mempunyai pengetahuan yang cukup (unsophisticated) tentang kegiatan bank (Avdasheva dan Yakovlev, 2000).

Jensen dan Meckling (1976) berpendapat terdapat kecenderungan agen bersikap oportunis. Hal ini tidak lepas dari penjelasan Eisenhardt (1989) bahwa teori keagenan mengasumsikan bahwa, (1) manusia mengutamakan preferensi pribadi (self interest), (2) manusia 
memiliki keterbatasan rasionalitas (bounded rationality), dan (3) manusia cenderung menghindari risiko (risk aversion). Dengan demikian adanya asimetri informasi mengakibatkan pengelolaan bank tidak sesuai dengan peraturan yang berlaku, salah satunya yaitu tidak transparansi pengelolaan. Bentuk tidak transparansi dalam penelitian ini adalah Internet Financial Reporting Disclosure.

Mekanisme monitoring melalui mekanisme internal di industri perbankan memiliki tujuan yaitu untuk memastikan bahwa agen bertindak sesuai kontrak dan untuk memenuhi kepentingan masyarakat. Monitoring yang optimal menghasilkan suatu governance outcome yaitu berkurangnya konflik kepentingan antar pihak yang berkepentingan.

\section{Komisaris Independen dan Internet Financial Reporting Disclosure}

Komisaris Independen merupakan elemen yang penting dalam memonitori proses pengungkapan laporan keuangan perusahaan (Klein, 2002) dan mempengaruhi reliabilitas dari laporan keuanngan (Anderson et al., 2004). Karena Komisaris Independen tidak terpengaruh oleh manajemen, maka mereka cenderung mendorong perusahaan untuk mengungkapkan informasi yang lebih luas kepada para stakeholder-nya (Ratnasari, 2011). Komisaris Independen memainkan peran penting dalam mengawasi jalannya perusahaan dalam meningkatkan keandalan laporan keuangan perusahaan sehingga diharapkan dapat meningkatkan kepercayaan dalam pengungkapan laporan keuangan, termasuk internet financial reporting disclosure (Kelton dan Yang, 2008) dan juga untuk menjamin sistem pengendalian internal terus berjalan (KNKG, 2006).

Penelitian Kelton dan Yang (2008); Mazzotta dan Brozetti (2013) dan Parlak kaya et al. ( 2015), menunjukkan pengaruh positif Komisaris Independen terhadap Internet Financial Reporting Disclosure. Beberapa bukti empiris menujukkan bahwa Komisaris Independen memainkan peran yang efektif dalam meningkatkan transparansi penungkapan, khususnya internet financial reporting disclosure. Sehingga laporan keuangan yang diungkapkan perusahaan akan lebih transparan akuntabel. Dengan demikian hipotesis Penelitian sebagai berikut: H1 : Proporsi Komisaris Independen berpengaruh positif terhadap Internet Financial Reporting Disclosure

\section{Ukuran Komite Audit dan Internet Financial Reporting Disclosure}

Komite Audit sangat penting dalam meningkatkan kualitas pelaporan keuangan (Andersonet al., 2003), membantu mengurangi kecurangan dalam penyajian laporan keuangan (Beasley et al., 2000; Klein, 2002). Hasil penelitian Abdillah (2013) membuktikan ukuran Komite Audit berpengaruh positif terhadap Internet Financial Reporting Disclosure. Komite Audit bertugas memberikan suatu pandangan tentang masalah akuntansi, laporan keuangan dan penjelasannya, sistem pengawasan internal serta auditor independen (Warsono et al., 2009).

Dengan demikian ukuran Komite Audit yang memadai disimpulkan secara umum dapat menghindari terjadinya masalah keuangan sehingga diharapkan dapat meningkatkan kepercayaan investor terhadap internet financial reporting disclosure yang disajikan perusahaan. Dengan demikian hipotesis Penelitian sebagai berikut:

H2 : Ukuran Komite Audit berpengaruh positif terhadap Internet Financial Reporting Disclosure

\section{Frekuensi Rapat Komite Audit dan Internet Financial Reporting Disclosure}

Pertemuan atau rapat Komite Audit berfungsi sebagai media untuk melaksanakan berbagai perbaikan atau evaluasi yang dibutuhkan, yang termasuk memastikan kualitas laporan keuangan. Frekuensi dan isi pertemuan Komite Audit dipengaruhi oleh berbagai hal salah satunya yaitu tugas, tanggung jawab, dan ukuran perusahaan. Berdasarkan Peraturan Bank Indonesia No. 8/4/PBI/2006 disebutkan bahwa Komite Audit mengadakan rapat sekurang-kurangnya 4 kali dalam satu tahun.

Collier dan Gregory (1999) menyebutkan bahwa frekuensi pertemuan Komite Audit yang lebih sering memberikan mekanisme pengawasan dan pemantauan kegiatan keuangan yang lebih efektif, meliputi persiapan dan pelaporan informasi keuangan perusahaan.

Penelitian Kelton dan Yang (2008); Puspitaningrum dan Atmini (2012); Parlakkaya et al. (2015) menunjukkan bahwa Frekuensi Rapat Komite Audit berpengaruh positif terhadap Internet Financial Reporting Disclosure. Dengan demikian pertemuan Komite Audit diharapkan meningkatkan Internet Financial Reporting Disclosure melalui fungsi pegawasannya dan pemberian sarannya yang khusunya, sehingga diharapkan kepercayaan stakeholder dapat meningkat. Dengan demikian hipotesis Penelitian sebagai berikut:

H3 : Frekuensi Komite Audit berpengaruh positif terhadap Internet Financial Reporting Disclosure

\section{Keahlian Komite Audit dan Internet Financial Reporting Disclosure}

Menurut Peraturan Bank Indonesia No. 8/4/PBI/2006 bahwa anggota Komite Audit wajib memiliki paling kurang satu anggota yang berlatar belakang pendidikan dan keahlian di bidang akuntansi dan/atau keuangan. Hal ini dikarenakan agar Komite Audit berfungsi secara efektif dan diharapkan kinerja Komite Audit juga akan lebih tinggi. Serta dapat meningkatkan kualitas internet financial reporting disclosure dan mengurangi perilaku oportunistik manajer (Puspitanigrum dan Atmini, 2012) yang diharapkan dapat meningkatkan kepercayaan stakeholder. Penelitian Kelton dan Yang (2008) serta Yapet al. (2011) menemukan bukti bahwa semakin banyak Komite Audit yang mempunyai keahlian keuangan maka akan meningkatkan transparansi dalam internet financial reporting disclosure. Sementara 
Felo et al. (2004) menyatakan bahwa keahlian Komite Audit di bidang keuangan berpengaruh positif dengan kualitas laporan keuangan. Dengan demikian hipotesis Penelitian sebagai berikut:

H4: Keahlian Komite Audit di bidang keuangan berpengaruh positif terhadap Internet Financial Reporting Disclosure.

Proporsi Anggota Komite Audit Independen dan Internet Financial Reporting Disclosure.

Komite Audit memiliki tugas pengawasan dalam proses pelaporan keuangan dengan cara mengurangi manipulasi dan menjamin informasi berkualitas bagi investor (Klein, 2006). Agency problem antara manajer dengan investor diharapkan akan berkurang dalam perusahaan dengan adanya Komite Audit. Proporsi anggota Komite Audit yang independen sangat penting karena dapat meningkatkan fungsi dari Komite Audit itu sendiri. Blue Ribbon Committee (1999) menyatakan bahwa independensi adalah hal yang paling penting dalam Komite Audit yang akan meningkatkan efektivitas Komite Audit. Di Indonesia proporsi anggota Komite Audit yang independen diatur dalam Peraturan Bank Indonesia No. 8/4/PBI/2006. Dalam peraturan tersebut dinyaktakan bahwa Komite Audit bertindak secara independen dalam melaksanakan tugas dan tanggung jawabnya.

Penelitian Bronson et al. (2009), membuktikan bahwa fungsi Komisaris Independen akan lebih mudah tercapai jika dibantu oleh Komite Audit sepenuhnya merupakan anggota yang independen. Sehingga diharapkan proporsi anggota Komite Audit yang independen dapat meningkatkan objektivitas dari internet financial reporting disclosure yang diungkapkan perusahaan. Dengan demikian hipotesis Penelitian sebagai berikut:

H5: Proporsi anggota Komite Audit Independen berpengaruh positif terhadap Internet Financial Reporting Disclosure

\section{Gambar. 1 Skema Konseptual Penelitian}

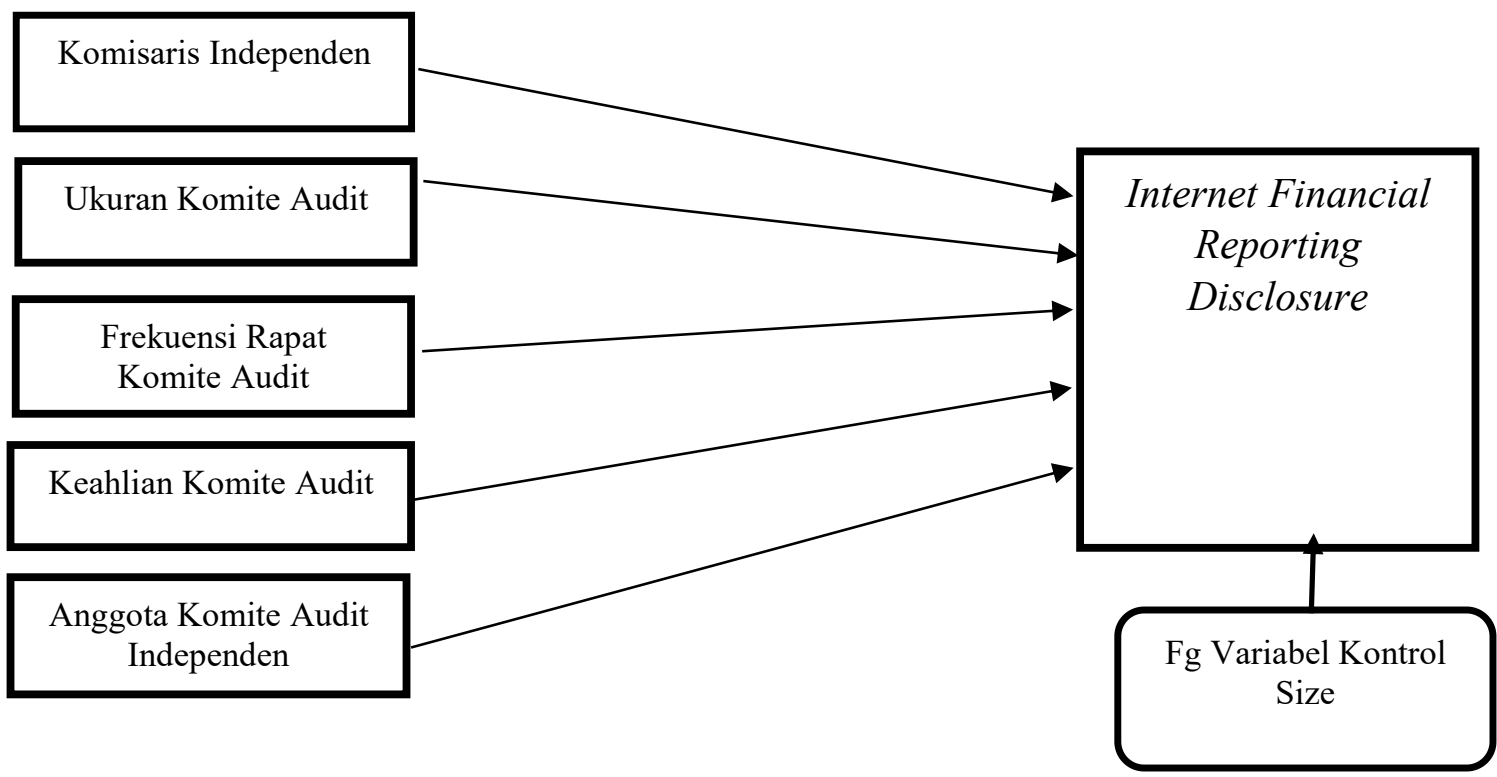

\section{METODE PENELITAIN}

Sampel penelitian ini yaitu industri perbankan yang terdaftar pada Bank Indonesia periode 2011-2014. Alasan pemilihan sektor perbankan dalam penelitian ini karena industry perbankan rawan terjadi moral hazard. Dan alasan pemilihan tahun penelitian 2011-2014 didasarkan pada berlakunya Peraturan Bank Indonesia Nomor 7/50/PBI/2005 yang mewajibkan perbankan untuk memiliki website perusahaan serta menampilkan internet financial reporting disclosure. Jumlah data observasi sebesar 360 data.

Penelitian ini menggunakan analisis regresi berganda yang digunakan untuk mengukur hubungan antara dua variabel atau lebih dan menunjukkan arah hubungan antara variabel dependen dan independen (Ghozali, 2011 :96). Menurut Ghozali (2011), uji asumsi klasik terdiri dari: (1) uji normalitas; (2) uji multikolinearitas; (3) uji heteroskedastisitas; dan (4) uji autokolerasi. Persamaan regresinya sebagai berikut:

IFRD $=\beta 0+\beta 1$ KI $+\beta 2$ UKA $+\beta 3$ FKA $+\beta 4$ KKA $+\beta 5$ IKA $+\beta 6$ Size $+\varepsilon$ 


\section{Keterangan:}

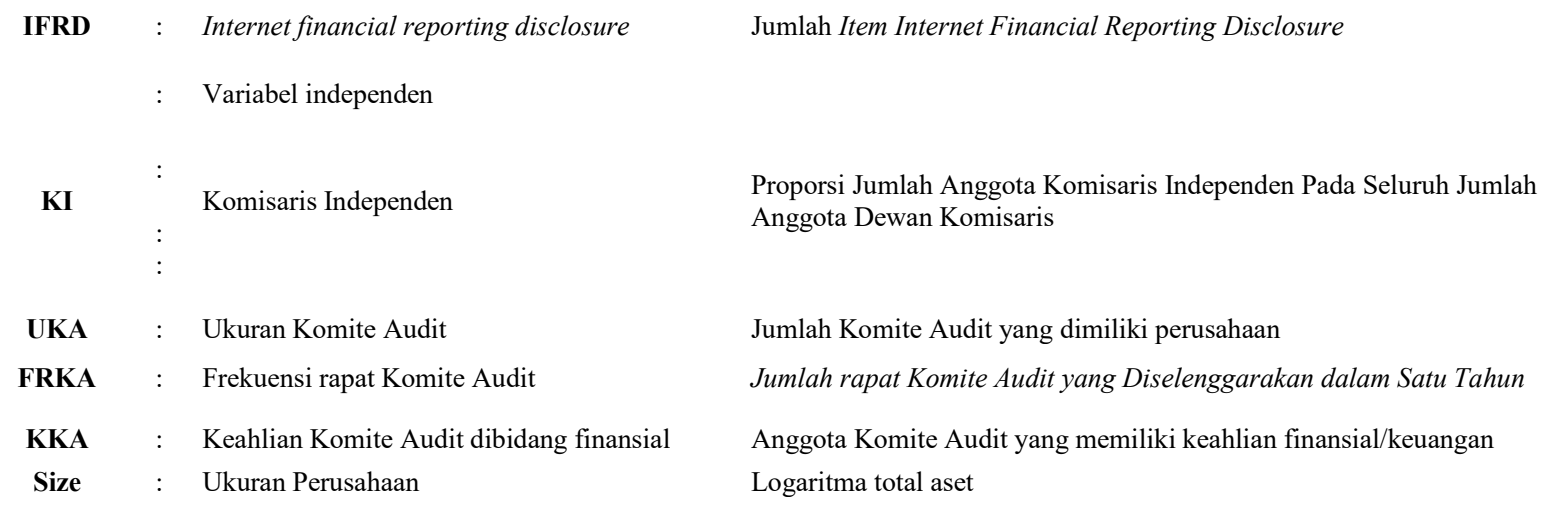

\section{HASIL DAN PEMBAHASAN}

Hasil pada Tabel 1 menunjukkan bahwa nilai rerata (mean) dari variabel Internet Financial Reporting Disclosure (IFED) sebesar 0,86284 yang berarti nilai sebesar $86 \%$ dari dari perhitungan 30 item pengukuran yang mengacu pada Peraturan Bank Indonesia No.7/50/PBI/2005 telah diungkapkan dalam laporan keuangan melalui internet.

Tabel 1

Statistik Deskriptif

\begin{tabular}{|c|c|c|c|c|c|}
\hline Variabel & $\mathbf{N}$ & Minimum & Maksimal & Mean & $\begin{array}{c}\text { Std. } \\
\text { Deviation }\end{array}$ \\
\hline IFRD & 360 & 0,37 & 1 & 0,8626 & 0,12889 \\
\hline KI & 360 & 0 & 1 & 0,5755 & 0,25245 \\
\hline UKA & 360 & 0 & 8 & 3,3556 & 1,39087 \\
\hline FKA & 360 & 0 & 49 & 10,2472 & 8,56419 \\
\hline KKA & 360 & 0 & 1 & 0,521 & 0,30391 \\
\hline IKA & 360 & 0 & 1 & 0,8491 & 0,30936 \\
\hline Size & 360 & 26 & 40 & 30,6111 & 2,2164 \\
\hline
\end{tabular}

Nilai rata-rata untuk Komisaris Independen (KI) memiliki nilai 0,57 atau 57\%, hal ini menunjukkan bahwa perusahaan perbankan rata-rata telah memiliki anggota Komisaris Independen sebanyak 58\% dari Proporsi Dewan Komisaris. Sesuai dengan Peraturan Bank Indonesia No. 8/4/PBI/2006, tentang ketentuan jumlah Komisaris Independen sekurang-kurangnya 50\% dari jumlah seluruh anggota dewan komisaris.

Nilai rata-rata untuk variabel Ukuran Komite Audit(UKA) memiliki rerata sebesar 3,3583 yang menunjukan bahwa rata-rata perusahaan telah memenuhi kriteria yang ditetapkan Peraturan Bank Indonesia yaitu minimum anggota Komite Audit sebanyak tiga (3) orang. Nilai rata-rata untuk variabel Frekuensi Rapat Komite Audit (FRKA) memiliki rerata sebesar 10,24 kali pertemuan dalam satu tahun. Tingginya rata-rata rapat yang dilakukan oleh Komite Audit ini menunjukkan tingginya aktivitas Komite Audit dalam menjalankan tugasnya. Hal tersebut menunjukkan bahwa perusahaan telah memenuhi peraturan yang ditetapkan oleh Bank indonesia.

Nilai rata-rata untuk variabel Keahlian Komite Auditdi Bidang Finansial (KKA) memiliki rerata sebesar 0,52 atau sebesar 52\% anggota Komite Audit memiliki latar belakang pendididkan maupun pengalaman di bidang keuangan/akuntansi.

Nilai rata-rata untuk variabel Independensi Komite Audit (IKA) memiliki rerata sebesar 0,849 atau sebesar 85\% anggota Komite Audit yang dimiliki perusahaan merupakan anggota Komite audit yang independen. Hal ini menunjukkan bahwa tingkat proporsi anggota 
Komite Audit yang independen di Indonesia telah sesuai Peraturan Bank Indonesia yaitu minimal 51\% anggota Komite Audit merupakan komisaris independen dan pihak yang independen.

Nilai rata-rata untuk variabel kontrol yaitu Size (Size) memiliki rerata sebesar 30,61\% Size akan berkaitan dengan pengungkapan yang dilakukan perusahaan. Hal ini mengurangi biaya agensi, perusahaan yang lebih besar mengungkapkan informasi yang lebih banyak. Hasil pengujian hipotesis menggunakan program pengolah data statistik dengan analisis regresi linier berganda.

Tabel 2.

Hasil Analisis Regresi

\begin{tabular}{lccc}
\hline Variable & Coefficient & Std. Error & P-Value \\
\hline Constants & & 0,096 & 0,002 \\
KI & 0,009 & 0,03 & 0,755 \\
UKA & 0,026 & 0,006 & 0 \\
FKA & 0,002 & 0,001 & 0,041 \\
KKA & 0,09 & 0,02 & 0 \\
IKA & 0,123 & 0,042 & 0,004 \\
SIZE & 0,009 & 0,003 & 0,002 \\
\hline R Square & 0,256 & & \\
& & & \\
Adjusted RSquare & 0,24 & & \\
$F$ & 16,542 & & \\
Sig & 0,000 & & \\
\hline
\end{tabular}

Koefisien Determinasi (Adjusted R-Square) pada Tabel2 didapatkan hasil sebesar 0,24 atau 24\%, artinya variasi pada variabel Internet Financial Reporting Disclosure (IFRD) dapat dijelaskan sebesar 24\% oleh Variabel Komisaris Independen (KI), ukuran Komite Audit (UKA), frekuensi rapat Komite Audit (FKA), keahlian Komite Audit di bidan finansial/akuntansi (KKA), dan independensi Komite Audit (IKA) dengan Size sebagai Variabel kontrol sedangkan sisanya 76\% dijelaskan oleh variabel lainnya yang tidak dimasukkan dalam model. Uji kesesuaian model (F) sebesar 16,542 dengan tingkat signifikansi 0,000, artinya model dapat digunakan untuk penelitian ini.

Pengujian hipotesis yang telah dilakukan menunjukkan bahwa variabel Komisaris Independen (KI) tidak memiliki pengaruh terhadap internet financial reporting disclosure dengan menunjukkan nilai t hitung sebesar 0,312 dan tingkat signifikansi sebesar 0,755 atau dengan kata lain hipotesis 1 (H1) ditolak. Berdasarkan teori agensi, adanya Komisaris Independen diharapkan memberikan iklim yang objektif, independen dan terbuka dalam melakukan pengawasan terhadap jalannya perusahaan termasuk dalam internet financial reporting disclosure. Namun dalam penelitian ini tidak terdapat pengaruh antara Komisaris Independen terhadap internet financial reporting disclosure. Gunawan (2016) menyatakan bahwa masih minimnya perusahaan yang memiliki Komisaris Independen sehingga belum cukup tinggi untuk membuat komisaris independen mendominasi kebijakan yang diambil oleh dewan komisaris, sehingga keberadaan komisaris indpenden belum mampu berfungsi sebagai mekanisme corporate governance dalam kaitannya peningkatan kualitas pengungkapan laporan keuangan melalui internet. Hal ini diduga pengawasan terhadap manajemen akan lebih efektif jika dibantu oleh peran Komite Audit sehingga dapat dihasilkan internet financial reporting disclosure yang lebih baik.

Hasil pengujian hipotesis menunjukkan bahwa variabel ukuran Komite Audit (UKA) memiliki pengaruh positif dan signifikan terhadap internet financial reporting disclosure dengan menunjukkan nilai thitung sebesar 4,113 dan tingkat signifikansi sebesar 0,000 atau dengan kata lain hipotesis 2 (H2) diterima. Rezaee (2007) menjelaskan bahwa komite audit berfungsi untuk melindungi kepentingan investor dengan menjalankan tanggung jawab pengawasan dalam area pengendalian internal, pelaporan keuangan, aktivitas audit dan kepatuhan dalam mengaplikasikan peraturan maupun regulasi. Semakin banyak anggota Komite Audit, semakin meningkat juga fungsi Komite Audit dalam mengungkapkan laporan keuangan melalui internet yang lebih baik. Komite audit dengan anggota yang cukup akan mampu membatasi perilaku opportunistic manajemen melalui informasi serta komite audit mempunyai motivasi yang unik yaitu lebih baik dalam pengawasan terhadap perkembangan dan pemeliharaan modal (Yapet al., 2011).

Hasil pengujian hipotesis menunjukkan bahwa variabel Frekuensi Rapat Komite Audit (FKA) yang diukur dengan mengjumlahkan total dari rapat yang diselenggarakan oleh Komite Audit dalam satu tahun, berpengaruh positif dan signifikan terhadap internet financial reporting disclosuredengan menunjukkan nilai thitung sebesar 2,048 dan tingkat signifikansi sebesar 0,041 atau dengan kata lain hipotesis 3 (H3) diterima. Tujuan utama dari rapat yang diadakan adalah untuk menciptakan sebuah koordinasi dari pengawasan pengungkapan laporan keeuangan dan melaksanakan pengawasan internal dan corporate governance (Puspitaningrum dan Atmini 2012). Semakin banyak frekuensi rapat tinggi koordinasi dalam pengawasan dan semakin efektif sistem pengendalian internal oleh Komite Audit dan mengurangi tindakan oportunistik manajemen dalam hal menyembunyikan sebagian atau seluruh informasi untuk kepentingan pribadi. Hal ini dapat meningkatkan pengungkapan laporan keuangan yang disajikan dalam web perusahaan. 
Hasil pengujian hipotesis meunjukkan bahwa variabel Keahlian Komite Audit di Bidang Akuntansi/Keuangan (KKA) berpengaruh positifdan signifikan terhadap internet financial reporting disclosure dengan menunjukkan nilai thitung sebesar 4,576 dan $\mathrm{t}$ ftingkat signifikansi sebesar 0,000 atau dengan kata lain hipotesis 4 (H4) diterima. Felo et al. (2004) menyatakan bahwa keahlian Komite Audit di bidang keuangan berhubungan positif dengan kualitas laporan keuangan. Keahlian keuangan komite audit merupakan background yang dimiliki oleh komite audit guna menunjang ke efektifan pelaksanaan kinerja dari komite audit (Rezaee, 2007). Kelton dan Yang (2008); dan Yap et al. (2011) menemukan bukti bahwa semakin banyak komite audit yang mempunyai keahlian keuangan maka akan meningkatkan transparansi dalam internet financial repoprting disclosure.

Hasil pengujian hipotesis menunjukkan bahwa variabel Proporsi anggota Komite Audit yang independen (IKA) memiliki pengaruh positif dan signifikan terhadap internet financial reporting disclosure dengan menunjukkan nilai thitung sebesar 2,902 dan tingkat signifikansi sebesar 0,004 atau dengan kata lain hipotesis 5 (H5) diterima. Klein (2002) dan Bedrad et al., (2004) menunjukkan bahwa proporsi anggota Komite Audit yang independen yang semakin tinggi akan mengurangi praktek manajemen laba. Bronson et al. (2009), menyatakan bahwa fungsi Komisaris Independen akan lebih mudah tercapai jika dibantu oleh Komite Audit sepenuhnya merupakan anggota yang independen. Sehingga dalam hasil penelitian ini, proporsi anggota Komite Audit yang independen dapat meningkatkan objektivitas dari internet financial reporting disclosure yang diungkapkan perusahaan.

\section{KESIMPULAN}

Karakteristik data yang nampak melalui analisis deskriptif ini menunjukkan rata-rata sebesar $86 \%$ ini menunjukkan bahwa tingkat internet financial reporting disclosure di Indonesia masih rendah, hal ini dikarenakan pengungkapan wajib di industri perbankan sesuai dengan peraturan Bank Indonesia.

Komisaris Independen tidak memiliki pengaruh terhadap internet financial reporting disclosure. Selanjutnya, berdasarkan hasil uji regresi berganda menunjukkan bahwa ukuran Komite Audit, frekuensi rapat Komite Audit, keahlian Komite Audit di bidang finansial/akuntansi, dan proporsi anggota Komite Audit yang independen memiliki pengaruh positif dan signifikan terhadap internet financial reporting disclosure.

Implikasi praktis dari penelitian ini adalah perlunya Bank Indonesia sebagai regulator meninjau kembali kriteria independensi dewan komisaris. Penelitian ini memiliki sejumlah keterbatasan yang diharapkan dapat diperbaiki melalui penelitian serupa dimasa yang akan datang, yaitu : Perusahaan disarankan untuk meningkatkan kepercayaan stakeholder pada perusahaan perbankan dengan cara meningkatkan transparansi internet financial reporting disclosure. Penelitian selanjutnya bisa memasukkan faktor-faktor corporate governance lain seperti struktur kepemilikan ke dalam model penelitian, agar pengaruh dari struktur kepemilikan yang juga mempengaruhi kebijakan internet financial reporting disclosure perusahaan ini tidak diabaikan.

\section{DAFTAR PUSTAKA}

Abbott, L., Park, Y. J., dan Parker, Susan. (2000). The Effects of AuditCommittee Activity and Indepence on Corporate Fraud. Managerial Finance. Vol 26. No 11, pp. 55-67.

Akbar F. N. (2014). Efektivitas Komite Audit Terhadap Ketepatan Waktu Pelaporan Keuangan: Studi Empiris pada Perusahaan Publik yang Terindikasi Kesulitan KeuanganTahun 2010-2012. Program Sarjana Fakultas Ekonomika dan BisnisUniversitas Diponegoro.

Almilia, L. S. (2009). Analisa Komparasi Indeks Internet Financial Reporting Pada Website Perusahaan Go Publik Di Indonesia. Seminar Nasional Aplikasi Teknologi Informasi.

Anand, S. (2008). Essentials of Corporate Governance. New Jersey: Wiley \& Sons.

Anderson, K. L., Gillan, Stuart dan Deli, D. N. (2003). Boards of Directors, Audit Committees, and the Information Content of Earnings. Weinberg Center for CorporateGovernance Working Paper No. 2003-04.

Anderson, R. C., Mansi, Sattar A. dan Reeb, D. M. (2004). Board Characteristics, Accounting Report Integrity, and the Cost of Debt.Journal of Accounting and Economics. Vol. 37,p p. 315-342.

Ashbaugh, H., Johnstone, K.,dan Warfield, T.(1999). Corporate Reporting On the Internet. Accounting Horizons, Vol. 13, pp. $241-57$.

Ball, R. (2006). International Financial Reporting Standards (IFRS): Pros and Cons for Investors.Accounting \& Business Research. Vol. 36 (4). 
Bapepam. (2012). Pembentukan dan Pedoman Pelaksanaan Kerja Komite Audit. Keputusan Ketua Badan Pengawas pasar Modal dan Lembaga Keuangan Nomor: KEP-643/BL/2012.

Beasley, M. S., Carcello, J. V., Hermanson, D. R. dan Lapides, P. D. ( 2000). Fraudulent Financial Reporting: Consideration of Industry Traits and Corporate Governance Mechanisms. Accounting Horizons. Vol. 14 (4), pp. 441-454.

Bédard, J., Marakchi-Chtourou, S., dan Courteau, L. (2004). The Effect of Audit Committee Expertise, Independence, and Activity on Aggressive Earnings Management, Auditing.Journal of Practice and Theory. Vol. 23, pp. 13-35.

Bipin, A. S., Bhojraj, dan Sengupta, P. (2005). The Association Between Outside Directors, Institutional Investors and the Properties of Management Earnings Forecasts. Journal of Accounting Research, Vol. 43, pp. 343-376.

Blue Ribbon Committee (BRC). (1999). Audit Committee Characteristic and Restatement: A Study of the Efficacy of Certain Blue Ribbon Committee Recommendations. New York: New York Stock Exchange and National Association of Securities Dealer.

Botti, L., Boubaker, S., Hamrouni, Amal dan Solonandrasana, Bernardin. (2014). Corporate Governance Efficiency and Internet Financial Reporting Quality. Review of Accounting and Finance.Volume 13, issue 1 pp.43-64.

Budisantoso, T. dan Triandaru, S. (2006). "Bank dan Lembaga Keuangan Lain”. Jakarta : Salemba Empat.

Collier, P. Dan Gregory, A. (1999). Audit Committee Activity and Agency Cost.Journal of Accounting and Public Policy, 18, Pp. 311 -332.

Debreceny, R.,Gray, G. R., dan Rahman, Asheq. (2002). The Determinants of Internet Financial Reporting. Journal of Accounting and Public Policy. Vol. 21, pp. 371-394.

DeZoort, F.T., Hermanson, D.R., Archambeault, D.S., and Reed, S.A. (2002). Audit Committee Effectiveness: A Synthesis of the Empirical Audit Committee Literature.Journal of Accounting Literature. Vol. 21 pp. 38-74.

Evans, T. G. (2003). Accounting Theory: Contemporary Accounting Issues. Australia: Thomson, Shouth-Western.

Felo, A.J., Krishnamurthy, S., Solieri, S.A. (2003). Audit committee characteristics and the perceived quality offinancial reporting: An empirical analysis. Working paper.

Financial Accounting Standards Board (FASB). (2000). Electronic Distribution of Business Reporting Information.

Fitriana, M. R. (2009). Analisis Pengaruh Kompetisi dan Karaktristik perusahaan terhadap Luas Pengungkapan Informasi Keuangan dalam website Perusahaan. Program Sarjana Fakultas Ekonomi Universitas Diponegoro.

Forum for Corporate Governance in Indonesia. (2005). “Corporate Governance Self Assesment Checklist Forum for Corporta Governance in Indonesia. $3^{\text {rd }}$ edition. www. fcgi.or.id

Ghozali, Imam. (2013). Aplikasi Analisis Multivariate dengan Program SPSS. Semarang: Badan Penerbit Universitas Diponegoro.

Hendro, T. Dan Rahardja, C. T. (2014). Bank dan Institusi Keuangan Non Bank di Indonesia. UPP STM YKPN.

Hodge, F.D., Kennedy, J.J., dan Maines, L.A., (2004). Does search facilitating technology improve the transparency offinancial reporting?.The Accounting Review.Vol. 79 (3), pp. 687-703.

Ika, A. S. Dan Gozali, I. (2011). Pengaruh KompleksitasiTugas Audt dan Tekanan Anggaran Waktu Terhadap Kualitas Audt dengan Moderasi Pemahaman Mengenai Sistem Informasi. Skripsi. Fakultas Ekonomi, Universitas Diponegoro, Semarang.

Internatinal Accounting Standard Committee (IASC). (1999). Bussiness Reporting on The Intenet.

Jensen, M.C. and Meckling, W. H. (1976), Theory of the Firm: Managerial Behavior, Agency Cost and Ownership Structure. Journal of Financial Economics Vol. 3. pp. $305-360$

Kartika, A. (2009). Faktor yang Mempengaruhi Audit Delay di Indonesia. Jurnal Bisnis dan Ekonomi (JBE). Vol 16(1), Hal. 1-17.

Kelton, A. S. dan Yang, Y. (2008). The Impact of Corporate Governanceon Internet Financial Reporting. Journal of Accounting and Public Polic. Vol 27, pp. 62-87.

Khan, T. (2006). Financial Reporting Disclosure On The Internet: An International Perspective. Faculty of Business and Law School of Accounting, Victoria University, Australia.

Khomisyah. (2005). Analisis Hubungan Struktur dan Indeks Corporate Governance dengan Kualitas Pengungkapan. Disertasi. Universitas Gajah Mada. Yogjakarta.

Khomsiyah dan Susanti. 2003. Pengungkapan Asimetris Informasi dan Cost of Capital. Proceeding.SimposiumNasional Akuntansi VII. Surabaya, 16-17 Oktober 2003, hal. 200-2009.

Klein, A. (2006). Audit Committee Board of Director Characteristic, and Earnings Management. Journal of Accounting and Economics. Vol. 33 No. 3, pp.375-400

Komite Nasional Kebijakan Governance (KNKG). (2002). Pedoman Pembentukan Komite Audit yang Efektif.

Komite Nasional Kebijakan Governance (KNKG). (2006). Pedoman Umum Corporate Governance Indonesia.

Lukviarman, N. (2005). Perspektif Shareholding Versus Stakeholding di dalam Memahami Fenomena Corporate Governance. Jurnal Siasat Bisnis. No. 1 Vol. 2 
Martani, D., Silvia V., Wardhani R., Farahmita A., Tanuwidjaya T. (2012). Akuntansi Keuangan Menengah Berbasis PSAK, Buku 1. Jakarta. Salemba Empat.

Mazzotta, R. dan Bronzetti, G. (2013). The Impact of Corporate Governanceon Internet Financial Reportingin Concentrated OwnershipCompanies. Organizational Change and Information Systems, Lecture Notesin Information Systems and Organisation 2.

Monks, Robert, A.G., dan Minow, N. (2008). Corporate Governance: $4^{\text {th }}$ Edition. USA: John Wiley \& Sons Inc.

Ojah, K. dan Mokoaleli-Mokoteli, T. (2012). "Internet Financial Reporting, Infrastructures and Corporate Governance: AnInternational Analysis. Review of Development Finance. Vol. 2, pp 69-83.

Organization for Economic Cooperation and Develpoment. (2006). Methodology for Assessing the Implementation of The OEDC Principles on Corporate Governance. www.oedc.org

Parlakkaya, R., Kahraman, U. dan Cetin H. (2015). "The Effects of the Corporate Governance on theLevel of Internet Financial Reporting: Evidencefrom Turkish Companies. World Academy of Science, Engineering and TechnologyInternational Journal of Social, Behavioral, Educational, Economic and Management Engineering. Vol. 9, No. 3.

Peraturan Bank Indonesia. (2001). Transparansi dan Publikasi Laporan Bank. Nomor 3/22/PBI/2001

Peraturan Bank Indonesia. (2006). Pelaksanaan Good Corporate Governance Bangi Bank Umum. Nomor 8/4/PBI/2006.

Pernyataan Standar Akuntansi Keuangan. (2009). Penyajian Laporan Keuangan.

Probal, D.dan Bose, S. (2007). Web-based corporate reporting in Bangladesh: an exploratory study,. The Cost and Management.Vol. 35, hal. 29-45.

Puspitaningrum, P. Dan Atmini, S. (2012). Corporate governance mechanism and the level of internet financial reporting: Evidence from Indonesian companies. Procedia Economics and Finance 2 ( 2012 ) 157 - 166.

Ratnasari, Y. (2011). Pengaruh Corporate Governance Terhadap Luas Pengungkapan Tanggungjawab Sosial Perusahaan di Dalam Sustainability Report. FE UNDIP Semarang.

Rezaee, Z. (2007). Corporate Governance Post - Sarbanes Oxley. First Edition. John Wiley \& Sons, Inc.

Sari, I. P. Dan Gozali, I. (2011). Analisis Faktor-Faktor yang Mempengaruhi Praktik Penerapan Internet Financial Reporting (IFR) Pada Perbankan di Indonesia. Skripsi. Fakultas Ekonomi, Universitas Diponegoro: Semarang.

Scott, W. R. (2003). Financial Accounting Theory. Edisi Ketiga. Pearson Education Canada Inc.

Sekaran, U. (2006). Metodologi Penelitian untuk Bisnis. Jakarta:Salemba Empat.

Surat keputusan Direksi PT Bursa Efek Jakarta (BEJ). (2000). Pembentukan Komite Audit Emiten dan Perusahaan Publik. Nomor Kep 315/ $\mathrm{BEJ} / 06-2000$.

Suwardjono. (2010). Teori Akuntansi: Perekayasaan dan Pelaporan Keuangan. Edisi Ketiga Cetakan Keempat. Yogyakarta: BPFE.

Tjager, I. N, et al. (2003). Corporate Governance: Tantangan dan Kesempatan Bagi Komunitas Bisnis Indonesia. PT. Prehallindo: Jakarta.

Warsono, S. Amalia,, F., dan Rahajeng, D.K.. (2009). Corporate Governance Concept and Model: Preserving True Organization Welfare. Center for Good Corporate Governance Fakultas Ekonomi dan Bisnis UGM.

Yap, D. K.-H., Saleh, D. Z., dan Abessi, D. M. (2011). Internet Financial Reporting And Corporate Governance In Malaysia. Australian Journal Of Basic And Applied Sciences, 5(10), 1273-1289. 